\title{
The Downfall of the Rehabilitative Ideal and the Establishing of a New Political Legitimacy in Swedish Crime Policy: 1965 to 1989
}

\author{
ROBERT ANDERSSON*
}

\section{Introduction}

In 1965 a new penal code was enacted in Sweden, a code that in itself was a manifestation of the rehabilitative ideals hold over Swedish crime policy. After more than thirty years of inquiries and reforms, the new code became a validation of individual prevention as the rationale for adjudication. Substantiating a rehabilitative ideal claim over crime policy, the penal law was in consequence framed as something that was there to facilitate the offender's readjustment to society. Nonetheless, within just a few years, the individual preventive reasoning and rationale of the code, as well as a crime policy built on the rehabilitative ideal, would come under harsh scholarly criticism. Set in motion was a process that, in less than twenty-four years, would see the abandonment of an individual preventive rationale in the penal code, replacing it with a retributive rationale built on what was conceptualised as penal value.

The effects of the downfall of the rehabilitative ideal during the 1970s has been either the starting point of or the framework for many analyses of crime policy in the last

* Associate professor in criminology, Institute of Police Education, Linnæus University.

This is an Open-access article distributed under the terms of the Creative Commons Attribution 3.0 Unported License (http://creativecommons.org/licenses/ by/3.0/), permitting all use, distribution, and reproduction in any medium, provided the original work is properly cited. 
decades. ${ }^{1}$ A turn to a repressive crime policy, mostly analysed in Anglo-Saxon countries, has also become a most common theme. Claims of a so-called punitive turn or of a penal populism are frequent when it comes to studies on crime policy. ${ }^{2}$ In these somewhat dichotomised explanations, John Pratt launches an even more dichotomising conceptualisation claiming that, contrary to penal populism and a punitive turn dominating the Anglo-Saxon world, there is also a Scandinavian exceptionalism. This exceptionalism manifests itself in terms of lenient sentences, low imprisonment rates and in a general tolerance towards crime and criminals framed as a sort of 'manifest destiny' of the social democratic welfare states of Scandinavia. ${ }^{3}$ Still one could argue that the many conceptualisations of punitiveness and penal populism remain mainly undefined, resulting in a situation wherein much of the related analysis is vague, and the historical developments that are to be clarified are asserted rather than explained. ${ }^{4}$

The object of this study is to contribute to a more empirically expounded trajectory of Swedish crime policy during the formative years of the 1970s to the early 1990s. Since there are few studies directly addressing the topic of the downfall of the rehabilitative ideal, one of the objects of this paper is to examine the scholarly critique that paved the way for the downfall of the rehabilitative ideal within Swedish crime policy. A second object is to look at the consequence of this downfall for Swedish crime policy. One argument made in this paper is that the downfall was not simply brought about as a logical consequence of the failure of the rehabilitative ideal as such, but also as a consequence of a wide array of claims from scholars with different scientific rationales. At stake was the right to 'tell the truth' about crime and criminals, and as a consequence, macro level sociological

1 Two pivotal studies are Garland, Culture of control: crime and social order in contemporary society (Oxford University Press 2001) and Simon, Governing through crime: how the war on crime transformed American democracy and created a culture of fear (Oxford University Press 2007). Garland's study has paved the way for many more, and through his work with the journal Punishment and Society Garland has more or less established crime policy studies as a field of its own. But crime policy studies also have a lengthier heritage and studies like Cohen, Visions of social control: crime, punishment and classification (Polity Press 1985), Rothman, Conscience and convenience: the asylum and its alternatives in progressive America (Little Brown 1980) and Garland, Punishment and welfare: a history of penal strategies (Gower 1985) are all part of it. The focus in much of the work on crime policy has been on punishment and the prison and Foucault, Discipline and punish: the birth of the prison (Vintage Books 1977) is often considered to be a major influence.

2 Garland 2001 and Pratt, Penal populism (Routledge 2007) are two major proponents of these theses.

3 Pratt's claim of a Scandinavian exceptionalism has been severely challenged by Scandinavian researchers. See Ugelvik and Dullum (eds.), Penal exceptionalism?: Nordic prison policy and practice (Routledge 2012).

4 Matthews, The myth of punitiveness, Theoretical Criminology (2005) pp. 175-201. Meyer and O'Malley are also sceptical of the many rather sloppy claims made about general occurrence of an all-embracing punitive turn. See Meyer and O'Malley, Missing the Punitive Turn? Canadian Criminal Justice, 'Balance' and Penal Modernism (Sydney University 2009). 
perspectives pushed out micro level medical-psychiatric explanations, while the juridical rationale saw a move from individual prevention to a just desert rationale.

A second argument made in this paper is that the downfall had effects on the political legitimacy of crime policy and thus also on the political field of crime policy. Losing the scientific legitimacy of individual prevention meant that legitimacy came to be upheld by politicians appealing to what is termed the general sense of justice. This restructuring of the field of crime policy in turn made it politically possible to launch policies that countered empirical findings made by criminology.

\section{Theoretical and Methodological Starting Point}

The theoretical and methodological framework of this paper builds on the Foucauldian concepts of governmentality and genealogy. ${ }^{5}$ Governmentality is a conceptual framework that Foucault developed in relation to the question of power and the state. In the work prior to the work on governmentality Foucault criticized a conceptualisation of power as repression, claiming instead that power was relational and productive and something primarily applied through interactions like teaching, reforming delinquents or performing diagnoses. Being criticized for omitting the workings of the state Foucault developed his ideas on governmentality. Governmentality focuses on the governing of life and the population, and explores the different forms governing may take. Just as with his critique of power as negative and repressive, governmentality builds on historicising and dissecting that which we take for granted and in this case it was the notions of the liberal democracy as a natural fact. Instead of taking liberalism as an ideology on what good government is Foucault frames liberalism as a governmentality - a way of governing combining both a conceptualisation of what is to be governed, as well as a conceptualisation of how to govern. Liberalism is also what Foucault see as a governing from a distance, a governing that works through the regulation of life by way of recommendations and thus governing is to structure the field of possible actions. Governing works through problematisation as a practice, it is by way of articulating problems and through finding the subsequent solution to these problems that governing works. Defining and thus knowing the problem is important since it incorporates producing that which is to be governed while at the same times producing ways of governing. The scientific knowledge of criminology and jurisprudence thus includes the creation of that which is to be governed, the criminal, as well as the knowledge on how to best govern this object.

The major work of Foucault when it comes to genealogy is Discipline and punish and when it comes to governmentality; The history of sexuality. Vol. 1: The will to knowledge (Penguin 1990). 
Pivotal to governing are two things: bio-politics and the population. As pointed out above, Foucault was criticised for not dealing with the state, but bio-politics is part of his analysis of the 'state' in the sense that the technique of discipline that Foucault highlights in Discipline and Punishment, a technique targeting the individual, at macro level is replaced by bio-politics and bio-power. Bio-politics addresses the population and its health and vitality; it is a politics of life focusing on the care and promotion of the population as the primary economic resource of the nation. Contrary to the rule of the sovereign, a rule that builds on the right over life, which manifests itself in the right to take life, bio-politics is a politics of life, controlling life and its existence for the good of the nation. Modern crime policy, criminology and rule of law are all part of this liberal governmentality and bio-politics, and the rehabilitative ideal and penal welfarism are prime examples thereof. The major rationale behind the rehabilitative ideal and its different expressions, like von Liszt's conceptualisation of the criminal as three distinct types, is a governing of the population aiming to maximise the usefulness of said population. Subsequently, the critique of the rehabilitative ideal and its consequences become analysable in terms of governmentality: What rationale of governing takes shape as a consequence of the downfall of the rehabilitative ideal and the succeeding crime policy-reformation?

Methodologically the paper explores the historical pedigree of present-day crime policy in Sweden, not as a linear development in terms of given 'origins', but as plural and sometimes contradictory pasts that reveal traces of the influence that power has had on truth. The downfall of the rehabilitative ideal has come to shape how we do and think about crime policy in Sweden today. But this history is not a pre-given one determined by 'historical facts and conditions', it is rather a contingent history - a certain way of assembling the trajectory of present-day views on crime policy. Theoretically and methodologically, this paper aims to do a genealogy, thus tracing the pedigrees of present-day conceptions of crime policy in a contingent history where power-relations shape the trajectory of said history. Doing a genealogy is doing a particular investigation into those elements that seem to be without history, or rather, are framed as being without history. The nexus of crime policy and criminological and jurisprudential knowledge often take this non-historical shape, framing itself instead as a natural reaction to the phenomena of crime.

The empirical material used in the paper consists of on the one hand of government bills, public inquiries and other reports and material produced by the Swedish government and the Swedish parliament (Riksdagen). On the other hand, the study uses publications made by researchers in the fields of criminology, penal law and crime policy addressing the question of crime and crime policy in Sweden and/or other relevant countries.

The paper consist of two parts. Part I takes as its aim explaining the scholarly critique of the rehabilitative ideal and how that unfolded over time. Part II looks to the political 
reactions and framing of policy that evolved in relation to the scholarly critique, but also how a policy developed without the need for scientific support. However, the paper starts with a historical look at the rehabilitative ideal in Sweden.

\section{The Rehabilitative Ideal in Sweden}

During the decades following the Second World War the rehabilitative ideal had come to have a strong hold over Swedish crime policy. This was mainly due to the simultaneity of three factors; the establishing of a social democratic welfare state, the hegemony of a medically based criminology and a firm belief in a scientific crime policy that could be used as a means of social engineering.

The hegemony of a medical criminology had much to do with the massive influence of Olof Kinberg (1873-1960). As a professor in psychiatry and a proponent of Lombroso's theory, Kinberg not only pursued research and started institutes, but was also often consulted as an expert in most public inquiries concerning crime and penal policy during the mid-decades of the $20^{\text {th }}$ century. ${ }^{6}$ Befriended with many politicians, amongst them the highly influential Karl Schlyter (1879-1959) who, apart from being a member of parliament for the social democrats, served as a minister of justice for a social democratic government in the years 1932-1936; Kinberg retained, for almost half a century, an unique position and opportunity to influence Swedish crime policy and the question on what should be seen as viable knowledge or not. Up to the 1960s Kinberg pretty much 'was' criminology in Sweden.

Schlyter, assisted by Kinberg, was a firm believer of the possibility of a scientifically devised crime policy that should be used as a means of obliterating crime. ${ }^{7}$ And it was through his work with the so-called strafflagberedningen (the penal law committee), in which Schlyter engaged the scholars he saw as best fitted in the work of producing a scientific crime policy, that criminology got established as a scientific subject matter in Sweden. Through the workings of Ivar Agge, with the support of Schlyter, criminology during the 1950s and 1960s became a subject of its own, this leading up to a chair in criminology at Stockholm university. ${ }^{8}$ Agge's, as well as Schlyter's, view on criminology was as a multi-disciplined support subject to penal law studies, thus giving penal law an empirical content. ${ }^{9}$

$6 \quad$ Qvarsell, Utan vett och vilja. Om synen på brottslighet och sinnessjukdom (Carlssons 1993).

$7 \quad$ Sundell, Karl Schlyter - en biografi (Nordstedts 1998).

8 On the history of criminology in Sweden see Pedersson, En fängslande vetenskap?: Kriminologi $i$ Sverige, 1885-1965 (Göteborgs universitet 2017).

9 See Agge, Den Kriminologiska vetenskapen in Kriminologi, eds. Agge et al. (Wahlströn \& Widstrand 1955). 
In reality, the rehabilitative ideal in Sweden would come to consist primarily of two practices: Firstly, an extensive use of coercive measures by applying administrative laws addressing social pathologies like drunkenness and so-called protective care of maladapted children. Secondly, by the implementation of so-called prison industries. ${ }^{10}$ 'First we build the factory, then we add the institution'11 was the manifestation of the rehabilitative ideal according to Torsten Eriksson, Head of the National Prisons and Probation Administration during the 1950s and 1960s. Reforming the culprit was thus installing a healthy work ethic and not much more.

A central aspect in the application of the exceedingly interventionist policy of the Swedish welfare state was the powers of the civil servant. Since Sweden is a civil law country, the work of public authorities and officials is governed by administrative law and by the courts. Social engineering in termers of forced custody or compulsory institutional care of those deemed unable to care for themselves in a proper way was governed by administrative law and by the courts; a juridical order that placed the courts at the hands of the civil servants.

The influence of a positivistic criminology on Swedish crime policy was most manifest in the question of liability. Accountability and legal responsibility was nothing more that metaphysical speculations - freedom of will was non-existent, thus punishing criminals because they were supposed to have acted in one way or another was ludicrous. This deterministic view of the culprit dominated the crime policy debate during the 1930s, 40 s and 50s and the ongoing revisions of the penal law were coloured by this kind of reasoning. However, it would be in the so-called Skyddslag that these ideas would cast their principal impression by proposing that, after the question of guilt was established, the choice of sanction should be settled by a committee of experts. ${ }^{12}$ Being one of two public inquiries behind the new penal code enacted in 1965, the proposal was not passed in its entirety. Instead it was paragraph 1:7 in the penal code that would come to regulate the choice of sanction as well as the severity of the sanction. The paragraph stated that 'the choice of sanction should, observing what is needed to maintain a general law abidingness, pay attention to the fact that the sanction shall be fitted out as to facilitate re-adjustment to society of the convicted.

10 Nilsson, Från cellfängelse till beteendeterapi. Fängelse, kriminalpolitik och vetande ca 1930-1980 (Egalité 2013).

11 Eriksson, The Correctional System of Sweden, Third United Nations Congress on the Prevention of Crime and the Treatment of Offenders. Stockholm 9-18.8.1965, 60.

12 SOU 1956:55, Skyddslag. This was also the final report produced by Strafflagberedningen and it meant the closure of a committee that had been working since 1938. 


\section{Part I: Enter the Critics - Opposing the Rehabilitative Ideal}

Even though there had been a debate in the late 1950s concerning the importance, or rather the unimportance, of general prevention as penal theory, the rehabilitative ideal seemed to stand quite unchallenged in Sweden in the mid-1960s. The new penal code confirmed this hegemony. However, in Norway, the professor of sociology of law, Vilhelm Aubert (1922-1988) and criminologist Nils Christie (1928-2015) had started to question the empirical claims surrounding the rehabilitative ideal. ${ }^{13} \mathrm{~A}$ legal criticism was also starting to build up in the Nordic countries led by the Norwegian professor of penal law, Johannes Andenæs (1912-2003), who had been arguing for a general preventive legitimisation of punishment instead of an individual preventive one. ${ }^{14}$ In 1967, Inkeri Antilla (1916-2013), a Finnish professor of penal law, published an article questioning a juridical reasoning based on individual prevention, claiming that it was juridical unsound since it focused on the actor and not on the act. ${ }^{15}$ Punishing the criminal and not the crime would amount to nothing more than speculations concerning future behaviour and could as a consequence not be the basis for sound legal reasoning.

The precursor of the critique of the rehabilitative ideal in Sweden consisted of a prisoners' rights movement originating in 1966. The national association on the humanization of correctional treatment, KRUM, was formed with the purpose of swaying public opinion on questions concerning Swedish correctional treatment, such as the use of in prison punishment like solitary confinement, hoping to persuade politicians to decrease the use of prisons. ${ }^{16}$ The KRUM-movement went on to inspire similar movements in Norway and Denmark, and even made an impact in the USA. Nonetheless, the critique emanating from the movement was originally not critical of the rehabilitative ideal as such, what was seen as the problem was rather the lack of treatment and the prison authorities' reliance on brute force. ${ }^{17}$

KRUM attacked the social democratic interpretation of the rehabilitative ideal. Crime and penal policy had been an important part of the efforts to reform society during the entire period of social democratic rule from 1932 and onwards. ${ }^{18}$ Within party politics the criticism delivered by KRUM on Swedish penal policy found a sounding board within

Aubert, Om straffens sociala funksjon (Universitetsforlaget 1959); Christie, Tvangsarbeid og alkoholbruk (Universitetsforlaget 1961).

14 Andenæs, Punishment and deterrence (University of Michigan Press 1974).

15 Anttila, Konservativoch radikal kriminalpolitiki Norden, Nordisk Tidsskriftfor Kriminalvidenskab (1967) pp. 237-251.

16 Andersson and Nilsson, Svensk kriminalpolitik (Liber 2017) pp. 110-112.

$17 \quad$ Nilsson 2013.

18 The social democrats had been in rule from 1932, and would be until 1976. This rule was either in coalition or by themselves. 
Folkpartiet ${ }^{19}$, and especially within their youth association. Quick to pick up on KRUM's criticism of the prison, Folkpartiet used the criticism as a way to condemn the social democratic welfare state. ${ }^{20}$ The criticism consisted in condemning the prison services, and especially the head of services, Torsten Eriksson (1906-1977), for not making the prisons and the workings of the prisons human and rehabilitative enough.

KRUM's and Folkpartiet's criticism of the prison system and the prison services was politically containable. By appointing a new head of the prisons services and a new minister of justice, while at the same time approving a new legal regulation concerning the serving of prison sentences, the rehabilitative ideal and individual prevention was maintained as the basis for crime policy. ${ }^{21}$

\subsection{The Penal Law as Class Law}

What really sparked the downfall of the rehabilitative ideal was when the penal law was framed as a class law underpinning the class society. ${ }^{22}$ By connecting the criticism of the rehabilitative ideal to class struggle and by depicting penal policy as a means of upholding the class society, the critics could draw on and merge with the general leftist societal criticism going on at the late 1960s and early 1970s in Sweden. There was however a political dividing line among the critics - you either supported a belief in penal policy as a means to a better society through reform or you maintained the position that the current penal system had to be abandoned to make a better society. The latter standpoint built on stressing the importance of class aspects and the class society in explaining the existence of the prison and the rehabilitative ideal, demanding the abandonment of all that made the class society possible. The former did not object to the means as such, i.e. the welfare state - these critics believed that it was mainly the scientific knowledge and the medical rationale that was wrong and they were thus supporters of social engineering, thinking it possible to produce the perfect society by scientific means. The major argument against the rehabilitative ideal was that it fortified the class society by making the locking up of

19 Folkpartiet is a centre-right party claiming adherence to the classical liberalism. During the late 1960s and early 70s, the party, and especially its youth association, was liberal in the American sense of the word, becoming almost socialistic in some sense. Nowadays the party has turned to more law and order rhetoric's pared with free-market liberalism, so-called neo-liberalism.

$20 \quad$ Nilsson 2013.

$21 \quad$ Lagen om kriminalvård $i$ anstalt (Kval 1974:203).

22 The so-called clientele-movement, incorporating KRUM, seemed, at first sight, to have been strengthened by a Marxist perspective and Marxist ideas, but the question is if, as Mitchell Dean points out, whether all that the radical movements of the 1960s and 1970s really did accomplished were to pave the way for the neo-liberal criticism of the welfare state. Dean, Governmentality: Power and rule in modern society (Sage 1999) p. 155. 
the lumpenproletariat into sane political action..$^{23}$ The penal law as class law was legitimized by the rehabilitative ideal since it hid the fact that what really caused crime was an unjust society. The argument made was that:

Laws aren't politically neutral. Their formulation is dependent upon the power and class aspects of the society that upholds them. Many laws protect certain social classes' interests. The privileged. Politically these laws can be unjust. But the realm of sickness and medicine doesn't hold the concept of injustice. Sickness is a causal process: classless. ${ }^{24}$

The medical rationale of the rehabilitative ideal hid societal and structural factors. Undetermined sentences, a pathological and individualistic explanation of crime, and differentiation of culprits according to their supposed need of treatment, were not logical outcomes of scientific progress and thus possible to verify empirically - they were ideological instruments used to further a society divided by class. ${ }^{25}$

The scholarly critique of the rehabilitative ideal took on two forms. On the one hand there was a juridical criticism, where the argument was that the rehabilitative ideals' juridical application, individual prevention, was in conflict with the most fundamental legal principles such as equality before the law, predictability, and the principles of legality and proportionality. The second line of scholarly critique was an empirical one. Inspired by the work done by Aubert and Christie ${ }^{26}$ social scientists started to produce research that showed that individual prevention had no real effect.

Establishing the Swedish National Council for Crime Prevention, $B R \AA$, in 1974 came to amplify the critique of the rehabilitative ideal since many of the scholars joining the council were themselves critics of the ideal. The creation of $B R \AA$ built on a belief in social engineering, and the launching of a national centre to coordinate the criminological research had been on the agenda since the 1940s. The fact that scholars critical to the rehabilitative ideal staffed $B R \AA$ naturally had consequences, instead of supplementing existing policy the council questioned the policy pursued. ${ }^{27}$

Elwin, Heckscher and Nelson, Den första stenen: Studiebok i kriminalpolitik (Tiden 1971). Håkansson, Brott - sjukdom - social kontroll in Behandlings som straff: 23 debatt inlägg om nordisk kriminalpolitik, ed. Nestius (Verdandi 1969) p. 122. My translation.

Andersson, Kriminalpolitikens väsen (Stockholms universitet 2002) pp. 62-65.

Aubert 1959, Christie 1961.

Brå-rapport 1974:1, Symposium kring kriminalpolitik - 14-15 januari i Saltsjö-Boo (Stockholm 1974); Brå-rapport 1974:3, Kriminalpolitiskt utvecklingsarbete (Stockholm 1974). 


\subsection{The Legal Argumentation against Individual Prevention}

Sanctioning the actor and not the act was what made individual prevention unjust and the legal scholars attacked what they saw as a mashing of a medical rationale based on clinical assessments, with a juridical rationale where the choice of sanction was not based on judicial reasoning, but on a medical one. The proposal from Skyddslag had been that the question of guilt should be decided by the court, while the questions concerning the sanction should be determined by medical experts; this due to the fact that criminals were pathological individuals in need of treatment. ${ }^{28}$ As mentioned, even though the proposal was not fully enacted, the new penal code still held a paragraph regulating the choice of sanction, making the choice of sanction into an individual preventive prognosis. What the legal scholars criticising the rehabilitative ideal wanted was an adjudication built on the competence and rationale of law as a science of its own. Amongst those capabilities were the abilities of asserting questions concerning guilt, intent, and responsibility. ${ }^{29}$

Individual prevention had to be abandoned due to the fact that there was scientifically 'true' way of correcting prisoners existed. Penal interventions were punishment and not treatment, and as such the result of power relations and the use of power. Giving allegiance to the jurisprudence of Cesare Beccaria and Jeremy Bentham, the scholars claimed that the power of the state had to be limited. But promoting classicism also meant promoting a jurisprudence that celebrated due process and proportionate punishment - the law should be, not an instrument for, but the limits of government. This line of argument was in itself also a criticism of social engineering. The proponents of a neoclassical school of law argued that the rule of law should be used as a means for limiting the power of the state. ${ }^{30}$

\subsection{Individual Preventions' Lack of Result}

The second line of critique of the rehabilitative ideal was an empirical one, and in Sweden Bengt Börjesson's studies initiated it all. ${ }^{31}$ However, looking more closely at the empirical criticism, one finds, as with the juridical critique, that the supporting structure of the disparagement is a different scientific rational: if the juridical critique built on framing legal reasoning as something inherently opposed to individual prevention, the empirical critique built on disqualifying the aetiology of individual prevention.

SOU 1956: 55.

Andersson 2002 pp. 65-78.

Andersson 2002 pp. 66-72.

Börjesson, Om påföljders verkningar (Almqvist \& Wiksell 1966); Börjesson and Ros, Straffets verkningar (Liber 1967). 
If we really wanted to understand crime, the argument of the macro level criminologists was that we had to look to social, economic, structural and systemic factors. In conclusion, the most disturbing feature of the rehabilitative ideal was the assumption that crime was caused by individual pathology.

The idea that criminality is a sickness that necessitates treatment turns the attention towards the individual, while at the same time taking attention away from the society that moulds his problems. Unjust distribution of societal means, poor social heritage etc., easily go to background when criminality is viewed from a medical perspective. ${ }^{32}$

The empirical criticism built on claiming that the root causes of crime were social, structural and economic factors. At stake was both the right to speak the truth about crime as well as the means for dominating the crime policy field. Establishing a subject matter, a methodology or a perspective as the dominating one or as 'the true expert science, in Sweden anyway, means that the researchers are given great leverage by being, amongst other things, those who are appointed as experts in public inquiries. In a discursive perspective speaking the truth is a way of structuring the field of possible actions and in that sense, being the science or discipline that has the right to speak the truth, gives those dominating the field the possibility to 'determine' what is included or excluded, what is scientific knowledge and what is not. ${ }^{33}$

One interesting aspect is how crime as a political topic came to expand substantially once the confinement of the subject primarily to issues concerning correctional treatment was abandoned. The move from the individualistic and pathological understanding of the criminal to a social understanding of crime reformulated the crime problem from being one concerned with deviant individuals, framing crime instead as an everywhere occurring phenomenon.

A sociological criminology was not something new as such. In Sweden, ${ }^{34}$ however, there had been few precursors, but internationally criminology could draw on its Durkheimian inheritance maintained by American sociology. Although both Marx and Durkheim was early on the scene, the impression still is that a methodological individu-

32 Håkansson 1969 p. 121 . My translation.

33 Andersson and Nilsson, Telling the Truth about Crime: The Past and Present of Swedish Criminology, Retfeerd (2015) pp. 79-93.

34 The first Swedish chair in sociology was established in 1947. It was given to a professor in philosophy, Torgny Segerstedt (1908-1999). At Stockholm University the first chair in sociology was appointed in 1954 and given to Gunnar Boalt (1910-2000). Both Segerstedt and Boalt wrote about crime and helped establish what was termed sociology of crime (kriminalsociologi). This was a subject-matter that was a complement to the medical criminology, whose purpose it was to prevent crime. Bengtsson and Molander, Den svenska sociologins födelse (Diadalos 1998). Agge 1955. 
alism, reducing societal facts to the actions of individuals, dominated the human sciences in Europe until the 1960s and 1970s, and the breakthrough of macro level criminology due to the criticism of the rehabilitative ideal cannot be underestimated. ${ }^{35}$ Interestingly enough, the majority of the researchers that came to dominate the criminological field in the Nordic countries from the 1970s and onwards, all had their careers facilitated by their criticism of the rehabilitative ideal. But even though the critics stressed the importance of social and economic factors as the root causes of crime, it would be the highlighting of the significance of the so-called opportunity structure that would come to have a major impact on crime policy from the mid-1980s an onwards.

\subsection{A New Crime Problem}

Relocating the causes of crime from the individual to societal factors also meant a relocation of the crime problem, moving it from being a pathological individual problem to becoming a societal problem instead. As long as crime was caused by individual pathology the crime problem was a problem of individuals committing crime. Interestingly enough, the researchers of the rehabilitative ideal did not consider petty crimes like shoplifting as real crimes. Real crimes were the outcome of sick individuals - shoplifting and other types of petty crimes were rather the outcome of rational calculations and could thus not be symptoms of a pathological personality. Real crimes, the crimes that were troublesome for society, were symptoms of sickness and pathology, and any sign of rationality falsified that notion. This also meant that the sudden and sharp rise in crime seen in the post-war 1950s was something that could not be explained by proponents of the rehabilitative ideal. The self-report studies of crime and deviant behaviour that became fashionable during the 1950s helped tearing down the assumptions of the rehabilitative ideal. The use of questionnaires, distributed to, for example, a high school class, in which the pupils themselves reported crimes committed proved that crime was something, not just rather normal, but quite common, at least amongst teenagers. The fact that self-report studies showed that acts of crime were common amongst teenagers made the crime problem depicted by the rehabilitative ideal obsolete. ${ }^{36}$ Stressing the commonness of crime, which was proved through self-report studies, as well as highlighting the importance of the crime opportunity structures for the prevalence of crime would become major arguments against the assumptions of the rehabilitative ideal.

35 Even though American sociology had had either a cultural or macro level perspective due to amongst others the so-called Chicago school, Lilly et al. point to the fact that the real influence of that kind of criminology on policy, even though the major works were written in the 1930s and 40s, would not happen until the 1960s. Lilly, Cullen and Ball, Criminological theory: context and consequences, 5th ed. (Sage Publications 2011).

36 In Sweden the first self-report studies were made in the late 1960s. Elmhorn, Självdeklarerad brottslighet bland skolbarn i Stockholm in Brott och straff, ed. Åkerman (Cavefors 1966). 
The status of crime as primarily a social and societal problem would stand uncontested until the mid-1990s when psychiatry made its sturdy reappearance in the field of crime policy.

\subsection{Implausible Solutions}

What was to become the key political problem with the downfall of the rehabilitative ideal was the inability of the new expertise to produce a politically feasible solution. Discarding the class society was not a politically viable solution, not even in Sweden in the 1970s. Nevertheless, the social, structural and economic factors that the critics framed as the root causes of crime and other social problems would have a major impact on policy, especially on youth policy, until the mid-1980s. In penal policy, and in particular concerning the effects of imprisonment, standpoints like nothing works and prisonisation would inform as well as affect policy. ${ }^{37}$ The conclusion that nothing works, i.e. that no measurable effect could be found in the different treatment-measures taken, was used as an argument against on the one hand the use of indeterminate sentences and on the other hand against the differentiation of punishment due to individual prognoses, but it was also used as an argument for strengthening equality before the law. Both the indeterminate sentence and the youth prison (also indeterminate) were abolished in the late 1970s.

Prisonisation on the other hand refers to a socialisation-process through which prisoners learn, accept and adapt to the norms and values of the prison. ${ }^{38}$ The occurrence of a prisonisation process was used as an argument against the use of prison since the process in itself made prisoners into recidivists. But abolishing the prison was never an option. Even the sternest among prison critics endorsed the claim that; used as a last resort, the prison was a general preventive and unavoidable necessary evil. ${ }^{39}$ The prison was framed as something to be used only as a last resort due to its negative consequences, a standpoint that would prevail in crime policy to the mid-1990s. ${ }^{40}$

The problem of the absence of expert solutions to the crime problem would increase with the solution advocated by the proponents of the neoclassical school of law. This because their solution was not so much a solution to crime as a reframing of what law and especially penal law should be. For the neoclassicists the objective was to produce a

37 Robert Martins, the man who coined the phrase nothing works, visited Sweden in the mid-1970s invited by the Swedish correctional services. Nilsson 2013.

38 In Sweden it was Ulla Bondeson's study of the prison that introduced the concept. Bondeson, Fången $i$ fångsamhället: socialisationsprocesser vid ungdomsvårdsskola, ungdomsfängelse, fängelse och internering (Norstedt 1974).

39 The downfall of KRUM is said to have been caused by a Marxist overtake of the organisation. The Marxists argued for the abolishment of the prison. Nilsson 2013.

40 Andersson and Nilsson 2017. 
penal law that excluded factors and considerations associated with individual prevention, and by endorsing due process; the legality principle and proportionate penalties, basic adjudication on questions concerning guilt and intent, a socially neutral adjudication process would be possible. But changing the rationale of adjudication was not enough, the criminalisation structure also had to be changed, i.e. the implicit rationale behind the political decision on whether to criminalise an act or not or whether to increase the punishment afforded a crime or not. Changing the criminalisation structure in practice meant increasing the culpability of economic crimes, while reducing the culpability of more traditional acquisitive crimes, since the harmful effects of white-collar crimes, according to the neoclassicists, were more serious. The criminalisation structure was also supposed to change due to the abandoning of an individual preventive reasoning for a due process rationale since this would also transform the penal law from being an instrument in the hands of the state into becoming a limitation upon the discretionary powers of the nation state.

Since most social scientists were critical of the prison and the use of it, they consequently also became sceptical of the idea that the criminal justice system should be founded on the principles of general prevention. Since much of the crime policy debate of the late 1970s and early 1980s came to be about general preventions - pros and cons, the debate in large part became internal and of interest only to scholars. Questions raised by the newly formulated social scientific criticism of general prevention consisted of questioning what general prevention actually entailed in in terms of penal policy and as penal theory and what the consequences would be in terms of the length of prison sentences and the amount of punishment if the criminal justice system was to be founded on its principles. Most social scientist were concerned that general prevention would produce the same social biases in penal policy as individual prevention had produced and on top of that general prevention would also lead to the introduction of very harsh prison sentences. The main argument voiced against general prevention was that politicians would not be able to refrain from using the politically 'easy' solution of harsher punishment, which would then lead to what is today called penal populism. ${ }^{41}$

\subsection{From General Prevention to Just Deserts}

The debate between neoclassicist and criminologist on the topic of the pros and cons of general prevention did not really come to an end as much as it was transformed into something else. It was at $B R \AA$ that the transformation of general prevention into just desert started. In 1977, with the publication of a booklet entitled Nytt straffsystem [A New Penal System] the question of which penal theory should be the rationale of the 
penal system reached its highpoint. A central legal principle was that of proportionate punishment. The principle was framed as something that would safeguard against indeterminate sentences and individualised punishment. But the principle of proportionate punishment of Bentham and Beccaria was instrumental and not intrinsic and as an instrumental principle it could be overridden by other considerations such as potential deterrence effects due to increased punishment. In a retributive penal theory on the other hand, the principle of proportionate punishment would be intrinsic and a retributive logic fitted well with the criticism voiced by the legal scholars against an adjudication process built on individual prevention. ${ }^{42}$ Instead of the forward-looking rationale of utilitarian reasoning, i.e. that consequences of future events are that which decide whether or not an act is morally right, the retributive rationale builds on assessing the moral blameworthiness of an act by judging the intentions of the actor. This backward-looking rationale places the intentions and the legal responsibility of the culprit at the core of the adjudication process. By placing the assessment of guilt at the centre of legal reasoning one also escapes the empirical speculations concerning future consequences of a sanction on a culprit, speculations that judges neither had schooling nor competence to do.

The Swedish version of just deserts was termed straffvärde. Straffvärde, or penal value, is supposed to be an assessment of the blameworthiness of a criminal act in terms of what it deserves as punishment. The argument voiced in Nytt Straffsystem was that the adjudication process should be guided by the penal value of the crime committed.

\section{Part II: The Political Reaction to the Downfall of the Rehabilitative} Ideal

Until the 1970s, crime policy in Sweden had been a relatively apolitical business. It was political in the elementary sense that politicians governed it, but crime policy had not been the political arena which it would become in the 1980s and 1990s. Crime policy had for the most part been seen as something best left to experts, thus manifesting a scientific optimism and a faith in scientific solutions. However, the critics of the rehabilitative ideal had, by pointing to the importance of social and economic root causes, shown that it was not the sciences, but rather policy, through social reform, that had the capacity to solve the crime problem. What the research community could do was to call attention to the factors that caused crime, but the task of dealing with these causes was a political one.

42 In 1976 Andrew von Hirsch made a case for a retributive penal theory in his Doing justice. Von Hirsch also collaborated with one of Sweden's more prominent legal scholars, Nils Jareborg. Jareborg has been the most influential penal theorist in Sweden during the last 40 years, making a strong case for just desert. Von Hirsch, Doing justice: The Choice of punishments (Northeastern University press 1976); Von Hirsch and Jareborg, Straff och propotionalitet, Nordisk Tidsskrift for Kriminalvidenskab (1987) pp. 300-324. 
The real political impact of the critique of the rehabilitative ideal came at the end of the 1970s. Following the general election of 1976, the centre-right opposition was able to form a government for the first time in forty-four years. This government faced, amongst other things, the task of formulating a crime policy without the support of an undisputed scientific foundation. The new scientific truth established, structuring the crime policy field, was that the opportunities available to the Ministry of Justice and the penal system, in terms of reducing crime, were more or less non-existent. Factors like the prisonisation effects and the general acceptance of nothing works greatly limited the arsenal of crime policy. These truths became accepted within the political sphere and it was emphasised that 'the criticism has in particular noted those experiences which show that placing offenders in prisons consistently leads to a poor level of rehabilitation and a high level of recidivism. ${ }^{43}$

The foremost problem arising due to the downfall was how to legitimise and rationalise not just crime policy, but also the existence of the penal system. Why have a penal system based on prisons, courts and police if it only resulted in negative effects? And why pursue a crime policy at all when the solution to the crime problem consisted of general welfare policy? The Swedish welfare state was at this time embraced by all the political parties of the Swedish parliament, Riksdagen, and the centre-right government had no plans on changing this. It became generally accepted during the 1970s that the crime problem primarily had social and economic root causes and thus was something to be addressed by social and welfare policies. However, the political acceptance of these truths, causing the political downfall of the rehabilitative ideal, left the penal system without a scientific legitimisation. The new legitimisation that would come to evolve would be a political one produced without any claims to scientific support - a legitimisation that discarded empirical support for popular support.

The beginning of a new legitimisation of the penal system started in the late 1970s when a policy of prioritisation was formulated. This was a policy based on claiming that certain types of crime, namely violent crime, drug crime, white-collar crime and youth crime, had priority over other types of crime. The argument made was that the problems with these types of crime were so pressing that they had to be dealt with firmly and as quickly as possible. The long-term preventive effects of welfare policy thus became politically implausible. These long-term measures needed time to work, time no longer politically obtainable. What the prioritised offence categories had in common was a political framing of their aetiology; instead of the generally accepted root causes, the prioritised crime types got framed as rational actions pursued on rational grounds. Finding inspiration in the general preventive reasoning of the neoclassical school of law, a deterrence reasoning found its way into the political argumentation. It was the supposed deterrence of patrolling police officers, the threat of punishment as well as early and sharp reactions 
from the penal system on juvenile delinquency that made the penal system indispensable. The supposed deterrent effects of the penal system became the political argument of the day. Crime prevention became outlined as something more direct, not including social measures. It was looked upon as a work that 'has to be pursued with the goal of reducing crime constituting a more immediate point of departure and [which] cannot be expanded to include generally aimed measures of a social nature. ${ }^{44}$ In practice, this also meant that combating crime, which is primarily what police work consists of, was transformed into and reframed as crime prevention - thus, equating the combating of crime with the prevention of crime was a way to give legitimacy and meaning to the penal system.

\subsection{Violent Crime as a Catalyst}

The deterrence logic and the promotion of the penal system as a solution to the crime problem would find an affiliation in the focus upon violent crime, a focus that has dominated Swedish crime policy since the early 1980s. As with the downfall of the rehabilitative ideal the focus on violent crime has its 'origins' in the radical 1960s and 1970s. Alongside the leftist critique there also emerged a feminist critique of the penal system. This critique consisted in the assertion that the unwillingness to seriously address the battered women's problem was due to the warped nature of the patriarchal society. The fact that the system allowed the battering of women to go on was viewed as a symptom of an unequal social order; a systematic subordination of women, which was just the tip of an iceberg of submission. Putting the battered women's problem on the agenda was thus a means to an end - to show that women were second-class citizens due to the fact that the political rights and privileges given to them in theory were denied them in practice. Formulated in the 1970s this was a harsh and potent critique of crime policy and the penal system, a critique that could not be taken lightly. Nonetheless, the political framing of the problem was made in terms of a legal shortcoming; the legal system allowed perpetrators to walk free because women dropped charges rather than to pursue prosecution. At the time, violent offences fell under private prosecution, thus prosecuting someone for a violent crime required a plaintiff willing to press charges. Accordingly, the political solution to the problem was to place violent crimes under public prosecution. ${ }^{45}$ Hence, the battered women problem was politically contained and transformed from a structural, social and general societal problem into a crime policy problem. ${ }^{46}$

The introduction of public prosecution would become a measure which provided the penal system with greater opportunities to act against violent crime, consequently

44 Regeringens budgetproposition 1980/81:100, bilaga 5., pp. 11-12. My translation.

45 Regeringens proposition 1981/82:43, Om ändringar i brottsbalken (åtalsregler vid misshandel); DsJu 1981:8, Åtalsreglering vid misshandel, Betänkande avgivet av 1977 års sexualbrottskommitté.

$46 \quad$ Andersson 2002 pp. 124-128; Andersson and Nilsson 2017 pp. 130-132. 
strengthening the depiction of the penal system as society's most central crime preventive resource. Placing violent crime under public prosecution also led to a substantial increase in the official statistics relating to these crimes, an increase that would come to serve as a basis for an even greater political interest. This increase was not however reflected in the victim surveys on exposure to crime conducted annually by Statistics Sweden. ${ }^{47}$

\subsection{The Dualisation of the Crime Problem}

In the early 1970s decriminalisation as well as reductions in the level of criminalisation was regarded as desirable, sound and vital parts of a rational crime policy. The introduction of a policy of prioritisation would come to change all this; it would come to readdress criminalisation, re-criminalisation and penal system measures making these measures into potential as well as preferable solutions to the crime problem. This process however needed a politically formulated crime problem that built on stressing so-called 'serious crime' as the major concern for the penal system. ${ }^{48}$ Refocusing crime policy on 'serious crime' at the beginning of the 1980s, was a move made in order to provide legitimacy to the penal system and the pursued crime policy and 'serious crimes' were portrayed as so precarious that they could not be left to 'generally aimed measures of a social nature'. However, the focus on 'serious crime' led to a division of the crime problem into two parts. With the prioritisation of serious crime, other types of crime were pushed into the background. This resulted in a division of the crime problem into serious crime and everyday crime. As concepts, these framings are unclear and undefined - but it is the lack of clarity that makes them so useful. As 'pictures' of crime they are clear and vivid - everyone 'knows' what a serious crime is. Legally, the seriousness of a crime is related to the punishment meted out for that act, and some attempts to define serious crime has been made, defining acts incorporating sentences of two years imprisonment or more as serious crimes is but one example. But the definitions of serious and everyday crimes is not a legal one but a political one and thus rhetoric. Looking at the way 'serious crime' has been defined, we find that it is in terms of offences that breach the state's monopoly over the use of violence, either by involving an element of violence and/or because the offences take place in what is referred to as public space. By contrast, 'everyday crime' comprises those offences to which people are exposed in the course of their daily lives, in their homes and cars, offences that are managed by means of various forms of insurance.

47 Whether the number of violent crimes are increasing or not has been a pivotal question since the 1980s. It has been reported that the number of crimes has increased, but compared to other data sources, such as victim surveys conducted annually by Statistics Sweden, this increase seems best explained by an increase in the readiness to report violent crimes. But when criminologists point this out it is seen as an insensitive response disclaiming the perception of the 'general public', i.e. of the politicians.

48 Andersson 2002 pp. 121-127. 
What was important with the dualisation of the crime problem was the reformulation of the responsibility for the crime problem; whereby the (welfare) state reformulated its area of responsibility at the same time as responsibility for certain aspects of the crime problem were transferred to what became referred to as the local community. The process; initiated at the beginning of the 1980s when the Social Democrats, returning to power, ${ }^{49}$ reformulated their crime policy in relation to the downfall of the rehabilitative ideal. This process built on emphasising the importance of the local community and individual responsibility for crime prevention. Consequently, the fundamental units of governance, the state and society, were redefined.

The state shifted from bearing full responsibility for the crime problem as a social problem to instead bearing responsibility for the maintenance of order in public space. This meant the transformation of the Swedish state from a welfare state into a judicial state bearing responsibility primarily for 'serious crime'. Society, by contrast, became disentangled from the state and became a unit in its own right - a civil society entitled the local community. The transformation of the welfare state into a judicial state, complimented by the local community, involved a governance where the citizen was to be made to take responsibility for those things that happened in the local community. As a result of that, the state would take its responsibility by upholding the monopoly over the use of violence and over the right to punish, thus framing the penal system as the states' 'boundaries' as well as its instrument. The state took as its responsibility to combat 'serious crime' in every form and to see to it that the criminals were punished. A policy of increased efforts on the part of the penal system, in terms of more police and stiffer penalties, was thus formulated.

The local community, on the other hand, was to assume responsibility for 'everyday crime'; local authorities, private individuals and voluntary associations such as neighbourhood watch projects, were to instigate the crime preventive community. ${ }^{50}$ These altered practices of governance are not unique to crime policy but rather constitute part of a general policy in Sweden which focuses an increasing amount of responsibility at the local authority level via the municipalisation of areas such as schools and the care of the elderly. This is a policy which conveys a desire for higher levels of private involvement and responsibility for the individual's own local community. ${ }^{51}$

49 DsJu 1985:5, Lokalt samarbete mot brott: Rapport från en hearing i Justitiedepartementet, DsJu 1996:59, Allas vårt ansvar: Ett nationellt brottsförebyggande program.

50 This policy is still the core of the social democrats crime policy and a new crime preventive program was presented during the fall of 2017 entitled Tillsammans mot brott (skr 2016/17:126).

51 Freedom of choice has been the main argument for deregulating former state monopolies. Many reforms have concerned services formerly provided by municipalities such as childcare, care of the elder, but also schooling, and medical care. Still financed by taxation, private interests now compete for tax money and a marketization of Swedish society is a fact. The aims of these marketizations are an active citizen wanting and embracing the responsibility of managing his or her own life on a deregulated market. 


\subsection{The General Sense of Justice}

The years 1982 to 1989 also came to see a reframing of the objective of crime policy in terms of for whom crime policy and the penal system was for; turning the interest from the criminal to the law-abiding citizen. At the core of this was the transformation of crime policy: from a welfare crime policy with the task of reforming society and reintegrating the criminal to a crime policy with the task of conserving society and protecting the law-abiding citizens. This meant making the legitimacy of crime policy dependant on how it was perceived by the citizenry, something that was conceptualised as the general sense of justice. The general sense of justice was defined as a common moral sentiment concerning how seriously criminal acts should be condemned. ${ }^{52}$

Soon the political appeal to the general sense of justice merged with an aspiration to take an interest in crime as a problem having consequences for people in the course of their daily lives. This transition can be seen as a move from an 'idealistic crime policy', basing its legitimacy on future goals, to a 'realistic crime policy', establishing its legitimacy by claiming to be a policy that is based in the 'here and now. Consequently, crime policy altered, from consisting as a forum for the reform of society, transformed into a political arena that was 'directly' subject to the expectations of society. In the process, the 'crime problem' shifted from being a matter of societal failure, becoming instead a question of protecting honest people from crime. The 'consumers' of the penal system in consequence moved from the socially disadvantaged perpetrator to the honest citizen. ${ }^{53}$

Reframing the object of crime policy in such a way built on separating the legitimacy of the penal system and crime policy from questions of quantitative empirical results in terms of crime rates or recidivism. Since the failure or success of policy was due to its ability to meet a general sense of justice, quantitative descriptions of the crime problem were replaced by qualitative descriptions. The seriousness of the crime problem was therefore no longer necessarily a question of how extensive the problem actually was, but rather how it was perceived. ${ }^{54}$ Thus, rather than being based on its ability to reduce the number

52 There is little or no support for the idea that there is a general sense of justice in terms of how one assesses the graveness of an offence; people judge criminal acts differently. See Jerre and Tham, Svenskarnas syn på straff (Stockholms universitet 2010); Brå-rapport 1982:1, Rättsmedvetandet i Sverige (Stockholm 1982); Brå-rapport 1996:1, Det allmänna rättsmedvetandet (Stockholm 1996).

53 Andersson 2002 pp. 134-135.

54 A telling example is violent crime - the perception of the problem advocated through media and politics projects a picture of a society in decomposition where violence, if not increasing, at least is becoming all the more brutal. When criminologists find little or no support for these doom and gloom discourses they themselves get questioned. Attacking criminologists and criminology is a common method amongst the editorial pages of rightist media. A little known fact is that the rate of homicide/manslaughter in Sweden, rating 1 per 100000 inhabitants, has held the same level for 260 years. 
of crimes committed, the legitimacy of crime policy became based on an appeal to what politicians framed as the citizens demands and expectations on crime policy. This has shown itself to be a strength, since politicians in this way are able to either disregard facts or choose from among available research claims or empirical 'facts' in order to legitimise their opinions, or they may quite simply dismiss scientific knowledge by referring to the public's sense of justice. By keeping its finger on the pulse of 'public perceptions' politics is able to access another form of knowledge on crime policy than that produced by the experts' statistical analyses of crime trends. In this way there arises a political knowledge of crime policy that is independent of the knowledge of the experts. ${ }^{55}$

\subsection{The General Sense of Justice, Penal Value and Social Engineering}

A driving force in the process towards legitimizing crime policy by referring to the general sense of justice, was the sanctioning system reform initiated by the downfall of the rehabilitative ideal. Enacted in 1989, the reform meant the introduction of two entirely new chapters to the penal code, replacing the one paragraph that prior to this had guided the adjudication process' meeting out of punishment. ${ }^{56}$ Establishing penal value and proportionate punishment as the grounds for meeting out punishment meant a firm regulation of the adjudication process. ${ }^{57}$ The meeting out of punishment consists of establishing what an act deserved in terms of punishment by way of determining, vis-à-vis blameworthiness, the concrete penal value of that act.

Nonetheless, it is not the courtroom use of penal value, but the political use of it that has furthered a crime policy based on qualitative assessments of the crime problem. Penal value was also to be used as bases for deciding whether to criminalise an act or whether to re-criminalize it (in terms of increasing the punishment). Here, penal value became a guideline in terms of the assumed abstract penal value of the act under evaluation. In sum, this entailed the abstract penal value was of an act was nothing more than 'harmfulness' of said act. Superseding preventive aspects the argument regarding criminalisation has been turned into a predominantly emotional assessment dressed up as morals. Criminalization being a political question soon meant the linking of the abstract penal value to the general sense of justice - making the blameworthiness of the act to be criminalised a

$55 \quad$ Andersson 2002 pp. 136-138.

56 Government Bill 1987/88:120, Changes in the penal code etc. (determining sentences and choices of sanction etc.).

57 Interestingly enough Christie, one of the instigators of the Nordic critique of the rehabilitative ideal, has criticized just deserts as something that will lead to a computer model of adjudication, i.e. that the exclusion of discretion or in Christies view, the human factor, will lead to an adjudication that does not take humanitarian aspects into considerations. Von Hirsch, on the other hand, has argued that limiting discretion is pivotal if one wants to decrease punishment in the US. 
question for said sense. On par with the general sense of justice, penal value has come to denote a crime policy that is largely normative and qualitative, thus absolving politicians from being responsible for the consequences of policy, reframing crime policy as an emotional venture playing on the feelings of the voters. Social engineering has accordingly been replaced by a moral engineering.

\section{Concluding Remarks}

The link between problems and preferred solutions is itself a construction that transforms an ideological preference into a rational governmental action..$^{58}$

One way of analysing the trajectory described above is in terms of a transformation of Swedish crime policy from social engineering to moral engineering. This is a transformation built on redefining the knowledge legitimising crime policy, moving from a criminological knowledge, built on quantitative and empirical aspects on policy, to a qualitative moral knowledge. Even though macro level criminology facilitated the downfall of the rehabilitative ideal in Swedish crime policy, it did not manage to install itself as the knowledge legitimising crime policy. All the while the new jurisprudence of just deserts furthered and expanded a political autonomy towards the scientific knowledge-production by stressing moral considerations as central to both adjudication and criminalisation. Building crime policy on the general sense of justice brought about an autonomous crime policy, a policy no longer focusing factual results, addressing instead the conceived results. A policy were the best possible result is bringing the pursued policy in accordance with general sense of justice, thus transforming crime policy into a moral engineering practice aiming at installing the right moral condemnation of crime.

In terms of governing this brings about a new way of governing and a new governmentality. The care for and optimizing of the population, central to the rehabilitative ideal, has been replaced by a care of the law-abiding citizen. Instead of an excluding inclusion, where the divergent subjects were separated from the heard only to be returned to the flock once 'cured', present-day Swedish crime policy builds on a including exclusion, whereby we learn how to belong to society by morally identifying the ones who doesn't belong. This move is visualised in the replacement of social engineering by a moral engineering - a practice built on making us aware of who has a, and who has not, a rightful access to society. Consequently, crime policy is no longer about integration and reintegration. Instead it has turned into a question of deservedness. 
A different governmentality also becomes visible in the changed relation to knowledge. The liberal governmentality has historically been dependent on scientific knowledge both to define the object of governing as well as the production of knowledge on how to govern those objects to the best of means. Scientific knowledge seems, since the downfall of the rehabilitative ideal, to have taken a different position. Its role in the problematisations of crime, of criminality and of the criminal has changed. The scientific focus, adopted by criminology as well as jurisprudence, during the rehabilitative ideal was that of the criminal, his drives and motives. The critics of the rehabilitative ideal lost sight of the criminal and focused instead on either moral aspects of the act or on the root causes behind the act. As a consequence, it was left to politics to problematise crime. The result became a problematisation of crime that moved from framing crime either as a sign of maladjustment or as a sign of societal insufficiencies that needed to be 'cured', to framing crime as a threat against society and social order.

Consequently, crime policy has come to be about protecting society and its law-abiding citizens from crime. Crime is thereby nothing stemming from society but something threatening it, thus crime is to be combated and punished and the criminal to adjust or perish. The rationale of the rehabilitative ideal and social engineering, i.e. to use crime and its occurrence as a means of reforming society, is thus lost and crime is solely looked upon as a threat to be dealt with. 